\title{
Differences between alcoholics and cocaine addicts
}

\section{seeking treatment}

\section{Running head: Alcoholics and cocaine addicts}

José J. López-Goñi ${ }^{1 *}$, Javier Fernández-Montalvo ${ }^{1}$ and Alfonso Arteaga ${ }^{1}$

${ }^{1}$ Departamento de Psicología y Pedagogía, Universidad Pública de Navarra, Campus de Arrosadía s/n, 31006 Pamplona, Spain

*Requests for reprints should be addressed to José J. Lopez Goñi, Departamento de Psicología y Pedagogía, Universidad Pública de Navarra, Campus de Arrosadía s/n, 31006 Pamplona, Spain, Tel.: + 0034948169 243; Fax: + 0034948169891 (e-mail: josejavier.lopez@unavarra.es) 
Abstract

Aims: This study explored the characteristics of a representative sample of patients who were addicted to either alcohol or cocaine, comparing the profiles of both types of drug users. Methods: A sample of 234 addicted patients (109 alcoholics and 125 cocaine addicts) who sought outpatient treatment in a Spanish clinical centre was assessed. Data on socio-demographic, consumption, psychopathological and maladjustment characteristics were collected using the European Addiction Severity Index (EuropASI), the Symptom Checklist-90-Revised (SCL-90-R) and the Millon Clinical Multiaxial Inventory (MCMI-II). Results: Demographically, differences were observed with regard to age (alcoholics were older than cocaine addicts), employment (the alcoholic group had more labour problems) and family consequences (worse in alcoholics). The EuropASI results showed statistically significant differences in addiction severity, with alcoholics showing a greater severity than cocaine addicts. In terms of psychopathology, alcoholics presented more associated symptomatology than cocaine addicts. Conclusions: According to these results, patients with alcohol dependence have a different profile from patients with cocaine dependence, resulting in different repercussions for important areas of their lives. These differences should be taken into account when standard treatments for addiction are implemented.

Keywords: drug addiction; alcoholism; cocaine abuse; assessment; clinical differences 


\section{Introduction}

Knowledge about the issues surrounding drug consumption has increased considerably in recent years, undoubtedly because of the severity of addiction-related problems and the social concern about this subject. Clinically, this increased interest in addiction issues has led directly to more precise knowledge of the psychopathological aspects of addiction (e.g., comorbidities, dual pathologies, course and prognosis) (Fernández-Montalvo \& López-Goñi, 2010; Landa, Fernández-Montalvo, López-Goñi, \& Lorea, 2006; Lorea, Fernández-Montalvo, López-Goñi, \& Landa, 2009), the development of specific assessment tools (e.g., the European Addiction Severity Index [EuropASI] and ad hoc self-reports developed for specific substances) (López-Goñi, Fernández-Montalvo, \& Arteaga, 2012b) and the establishment of specific, empirically validated treatment programs (Fernández-Montalvo, López-Goñi, Illescas, Landa, \& Lorea, 2008; Secades \& Fernández-Hermida, 2003). In the social and educational fields, which are closely related to the study of addictive behaviours, this change in addiction knowledge has also been important, as highlighted by prevention programs aimed at atrisk adolescents and the development of universal prevention programs in the educational field (National Institute on Drug Abuse, 2003).

To continue this progress, a major challenge for the coming years is to establish specific patient profiles corresponding to the drug of abuse. Beyond the characteristics common to all addicts, it is important to know the specific profiles of consumers of different substances. This knowledge will allow for the tailoring of currently available treatments to the specific problems presented by addicted patients when they come to a clinical centre.

López-Goñi, J., Fernández-Montalvo, J., \& Arteaga, A. (2015). Differences between Alcoholics and Cocaine Addicts Seeking Treatment. The Spanish Journal of Psychology, 18, E2.

doi:10.1017/sjp.2015.3 
In Spain, the main demand for treatment in addicted patients is related to alcohol and cocaine problems. According to the latest data from the Spanish Observatory on Drug-Addiction (Observatorio Español de la Droga y las Toxicomanías, 2011), alcohol is the most commonly used drug in the country, and abuse of cocaine creates the most demand for treatment. Consequently, alcoholics and cocaine addicts make up the majority of patients who demand therapeutic assistance in Spanish clinical settings. For example, in recent studies of addicted patients in clinical settings in Spain, between 35\% and 45\% of patients were alcoholics, and between $45 \%$ and $60 \%$ were cocaine addicts (Arias et al., 2013; Arteaga, Fernández-Montalvo, \& López-Goñi, 2012; Asociación Proyecto Hombre, 2013; Fernández-Montalvo, López-Goñi, \& Arteaga, 2012a, 2012b; FernándezMontalvo, López-Goñi, Arteaga, \& Cacho, 2013; López-Goñi, Fernández-Montalvo, \& Arteaga, 2012a). In these same studies, only approximately $15 \%$ of treated patients abused other substances.

To address these addiction problems, Spanish addiction treatment centres tend to use standard treatment regimens. The treatment programmes are empirically validated according to the criteria established by the scientific community (Secades \& FernándezHermida, 2003). However, despite the essential need to adapt existing treatments to the specific characteristics of the patients, in Spain, few studies have specifically analysed the clinical differences between patients seeking treatment for problems with alcohol or cocaine, the two most widely used substances (Araque, De los Riscos, De la Casa, \& López-Torrecillas, 2004; Sánchez-Hervás, Tomás Gradolí, \& Morales Gallús, 2001). Knowledge of the specific and differential characteristics of clinical patients with alcohol or cocaine dependence allows for treatments tailored to the patients' specific needs. 
In this way, the main objectives of the current study were to determine the characteristics of a sample of addicted patients undergoing treatment and determine whether their profiles differed depending on the drug of consumption: alcohol or cocaine. To achieve these objectives, a group of alcoholics entering outpatient treatment was compared with a group of cocaine addicts in terms of various socio-demographic, consumption, psychopathological and adjustment variables. Based on the literature, the main hypothesis of this study was that alcoholics would be older and would present a more severe substance abuse profile, with more psychological and maladjustment consequences of their addictive behaviour. In contrast, cocaine addicts would be younger and would be better adjusted to daily life.

\section{Method}

The protocol for this study was approved by the ethics committees of the Public University of Navarra and of the Fundación Proyecto Hombre de Navarra.

\section{Participants}

The initial sample consisted of 285 consecutive addicted patients who sought outpatient treatment at the Proyecto Hombre Addiction Treatment Programme in Pamplona, Spain, from October 2010 to July 2012. This was a cognitive-behavioural intervention on an individual outpatient basis, aimed at abstinence, and it is not required to pay for treatment. The main therapeutic techniques were related to stimulus control and in vivo exposure, as well as relapse prevention. During the first 6 months the treatment included weekly sessions (45-60 minutes); during the last 6 months sessions were biweekly. Successful programme completion typically requires approximately 12 months and is achieved when a patient completes all therapeutic sessions.

López-Goñi, J., Fernández-Montalvo, J., \& Arteaga, A. (2015). Differences between Alcoholics and Cocaine Addicts Seeking Treatment. The Spanish Journal of Psychology, 18, E2. 
The patients had to meet the following admission criteria: a) meet the diagnostic criteria of alcohol or cocaine dependence according to the DSM-IV-TR (American Psychiatric Association, 2000), b) be between 18 and 65 years old, c) give their informed consent to participate in the study, and d) complete the three assessment sessions.

Fifty-one (17.9\%) of the 285 initial subjects did not meet the criteria mentioned above. Therefore, the final sample was composed by 234 subjects (109 alcoholics and 125 cocaine addicts). This is a convenience sample, but representative of Spanish substance abusers in outpatient treatment (Observatorio Español de la Droga y las Toxicomanías, 2011). The mean age of the individuals included in the study was 37.8 years $(S D=9.4)$; the sample included $189(80.8 \%)$ men and $45(19.2 \%)$ women. The socioeconomic level was middle to lower-middle class.

\section{Assessment}

The EuropAsi (Kokkevi \& Hartgers, 1995) is the European version of the Addiction Severity Index (McLellan, Luborsky, Woody, \& O’Brien, 1980). This measure, which has an interview format, yields two types of scores: the Interviewer Severity Ratings (ISR) and the Composite Scores (CS). The ISR assess the need for treatment in the following seven areas: a) general medical state, b) labour and economic situation, c) drug consumption, d) alcohol consumption, e) legal problems, f) family and social relationships, and g) psychiatric state. Severity scores range from 0 (no problem) to 9 (extreme problem) in each area, and the cut-off score for each area is 4 . These areas are directly related to the severity of consumption (López-Goñi et al., 2010). In this study, we also used the Composite Scores (CS) of the EuropASI. The CS were developed for research purposes; they are arithmetically based indicators of current (last 30 days) problem severity that range between $0.00-1.00$, with higher values denoting higher 
degrees of severity. They assess the following nine areas: a) general medical state, b) economic situation, c) labour satisfaction, d) alcohol consumption, e) drug consumption, f) legal problems, g) family relationships, h) social relationships, and i) psychiatric state. For the current study, the CS were calculated according to the method proposed by Koeter and Hartgers (Koeter \& Hartgers, 1997). The Spanish version of the EuropAsi was developed by Bobes, González, Sáiz and Bousoño (1996). In this study, both the ISR and CS were used because they offer complementary information (López-Goñi et al., 2012b).

Moreover, in this study, certain items of the EuropASI were used to obtain specific information about the presence of psychopathological problems in the sample (Psychiatric scale items 3, 4, 6, 7, 9, 10). Other items indicated the patients' level of adjustment in different areas: family and social relationships (Family and social scale items 10b-18b), labour situation (Employment and support scale item 8, 19, 20) and history of abuse (Family and social scale items 18A-18C).

The Symptom Checklist-90-Revised (SCL-90-R) (Derogatis, 1992) (Spanish version by González de Rivera (2002)) is a self-administered general psychopathological assessment questionnaire. It consists of 90 questions that are answered on a 5-point Likert-type scale, ranging from 0 (none) to 4 (very much). The questionnaire aims to assess the respondent's psychiatric symptoms. The SCL-90-R has been shown to be sensitive to therapeutic change and thus may be used for either single or repeated assessments. The SCL-90-R measures nine areas of primary symptoms: somatisation, obsessive-compulsive, interpersonal sensitivity, depression, anxiety, hostility, phobic anxiety, paranoid ideation and psychoticism. It also provides three indices that reflect the subject's overall level of symptom severity. The internal consistency of the measure ranges from .70 to .90 .

López-Goñi, J., Fernández-Montalvo, J., \& Arteaga, A. (2015). Differences between Alcoholics and Cocaine Addicts Seeking Treatment. The Spanish Journal of Psychology, 18, E2. doi:10.1017/sjp.2015.3 
The Millon Clinical Multiaxial Inventory (MCMI-II) (Millon, 1997) (Spanish version of Millon and Avila (1998)) is a self-report questionnaire with 175 true/false items. It was designed to identify clinical states and personality disorders that are similar to those referenced in the DSM-IV-TR. The MCMI-II contains ten basic personality scales: 1) Schizoid, 2) Phobic, 3) Dependent, 4) Histrionic, 5) Narcissistic, 6) Antisocial, 7) Aggressive/sadistic, 8) Compulsive, 9) Passive-aggressive, and 10) Self-destructive. In addition to the basic personality scales, there are three pathological personality scales: Schizotypal (S), Borderline (B) and Paranoid (P). The nine symptom scales of the MCMIII were not taken into account in this study as they are not relevant to the purposes of our research. The internal consistency of the measure ranges from .66 to .89.

Procedure

Once the clinical sample was selected using the previously described criteria, the assessment of the sample was carried out in three sessions before beginning the treatment. Each session took place once a week for three weeks; the time interval between sessions was the same for each participant. The subjects were interviewed by clinical psychologists who had eight or more years of experience in treating addictions and in applying the assessment tools used in this study. In the first session, data related to socio-demographic characteristics and drug consumption were collected using the EuropASI. The ISRs were calculated according to the 2-step methodology suggested by Bobes et al. (2008). In the second session, the presence of psychopathological symptoms was assessed using the SCL-90-R. Finally, in the third session, the personality characteristics were assessed using the MCMI-II. Because the combination of different substances is common in addicted patients, the group membership of each patient was determined according to the main substance that motivated the search for treatment (assessed by the EuropASI), 
together with the therapist opinion. After the assessment sessions, patients began the standard treatment provided by Proyecto Hombre for addiction.

Data analysis

Descriptive analyses were conducted for all variables. Bivariate analyses were employed using $\chi^{2}$ or t-test statistics, depending on the nature of the variables studied. Regarding multivariate analysis, a logistic regression analysis (forward method) was conducted to determine which specific factors were more relevant in differentiating between the groups studied. This analysis used the following models: 1) sociodemographic and consumption; 2) severity of addiction; and 3) clinical variables. A difference of $p<.05$ was considered significant. Statistical analyses were conducted using SPSS (version 15.0 for Windows).

\section{Results}

Comparison of socio-demographic and consumption variables

The comparison between alcoholics and cocaine addicts on socio-demographic characteristics showed statistically significant differences for all variables studied (table 1). Cocaine addicts were younger than alcoholics and were more likely to be male. Regarding marital status, cocaine abuse patients were more likely to be single, and with regard to employment, they were more likely to be occupationally active compared to alcoholics.

\section{Insert Table 1 here}

Regarding drug abuse characteristics, cocaine addicts were more likely to show poly-dependence than alcoholics, whereas alcoholics presented a higher frequency of daily consumption.

\section{Comparison of severity of addiction}

López-Goñi, J., Fernández-Montalvo, J., \& Arteaga, A. (2015). Differences between Alcoholics and Cocaine Addicts Seeking Treatment. The Spanish Journal of Psychology, 18, E2. doi:10.1017/sjp.2015.3 
The severity of each patient's addiction was evaluated using the EuropAsi (table 2). The patients who were receiving treatment for alcoholism presented with greater addiction severity than cocaine addicts in five of the seven areas scored by an interviewer: medical, employment/support, alcohol use, family/social and psychiatric. In contrast, cocaine patients presented with greater severity in terms of drug use and legal status. When composite scores were taken into account, alcoholics showed a more severe economic situation. Moreover, as expected, alcoholics showed a higher severity in the alcohol area and cocaine addicts in the drug use area.

\section{Insert Table 2 here}

\section{Comparison of clinical variables}

The entire sample showed moderately high scores on the SCL-90-R (approximately $60^{\text {th }}$ percentile) used to assess psychopathological symptoms (Table 3). There were significant differences between the two patient groups on two general scales (GSI and PSDI) and in two specific dimensions (depression and psychoticism). In all cases, alcoholics had higher scores than cocaine patients.

\section{Insert Table 3 here}

In comparison with cocaine abuse patients, alcoholics also had significantly higher Millon Clinical Multiaxial Inventory II (MCM-II) scores on six scales: Schizoid, Phobic, Compulsive, Self-destructive, Schizotypal and Paranoid.

\section{Comparison of maladjustment variables}

Regarding maladjustment variables, the whole sample presented with important repercussions in the areas studied. Comparison between groups showed several differences regarding various adaptation variables (Table 4): problems with siblings (more frequent in alcoholics), problems with intimate friends (more frequent in cocaine 
addicts), labour problems (mainly in alcoholics), debts due to consumption (more frequent in cocaine addicts), and severity of psychological symptoms (more depressive and anxiety problems in alcoholics; more hallucinations in cocaine addicts).

\section{Insert Table 4 here}

\section{Multivariate analysis}

The results from logistic regression analysis showed that model 2 (related to severity of addiction) was the model that explained a higher percentage of the variance (adjusted $\mathrm{R}^{2}=.837$ ). Specifically, the variables introduced by the model were ISR alcohol, ISR drugs and CS economic. These three variables correctly classified $90.1 \%$ of cases.

Insert Table 5 here

In contrast, model 1 (related to socio-demographic and consumption variables) correctly classified $84.1 \%$ of the cases, and model 3 (related to clinical variables) correctly classified $64.5 \%$ of the cases.

When logistic regression analyses were carried out separately with men and women, model 2 was the model that correctly classified the higher rate of cases.

\section{Discussion}

In this study, the profiles of patients addicted to alcohol and cocaine who seek treatment were analysed and compared. Abuses of these two substances are the two main drug problems in Spain (Observatorio Español de la Droga y las Toxicomanías, 2011). The goal of this study was to identify the different characteristics of both types of patients so that the existing treatment programmes may be adapted to the specific problems presented by the patients. The results obtained revealed the existence of significant 
differences between the two groups of addicted patients. These differences were observed in terms of socio-demographic, psychopathological and adjustment variables.

From a socio-demographic perspective, there were clear differences between the two groups of patients. Alcoholics were older (by more than 10 years), with more family impact (higher divorce rate) and labour impact (lower percentage of employment), and with more continuous consumption (daily, in most cases). For cocaine addicts, patients were younger, more likely to be single, employed with a paid job that allowed them to afford cocaine consumption, and showed less frequent consumption that was more focused on the weekends, most likely associated with leisure situations. An important finding to note is that poly-dependence was significantly higher in cocaine addicts. These data are consistent with the profiles found in other studies conducted in recent years (Asociación Proyecto Hombre, 2013; Observatorio Español de la Droga y las Toxicomanías, 2011).

Regarding addiction severity, the results for the EuropAsi variables were in the same direction. Alcoholics showed more severity in terms of medical status, employment situation, family and social relationships, and psychiatric state. Alternatively, cocaine addicts obtained higher scores in terms of general drug use and legal situation. These results are most likely related to socio-demographic differences. The profile of an alcoholic is that of an older person with more years of consumption and, consequently, with greater repercussions for daily life (Hatton et al., 2009). The results on the SCL-90R and MCMI-II supported this same idea, with significantly more psychopathological problems in alcoholics. These results are similar to those obtained in other studies (Bravo de Medina, Echeburúa, \& Aizpiri, 2007).

López-Goñi, J., Fernández-Montalvo, J., \& Arteaga, A. (2015). Differences between Alcoholics and Cocaine Addicts Seeking Treatment. The Spanish Journal of Psychology, 18, E2. doi:10.1017/sjp.2015.3 
The data related to maladjustment variables also showed significant differences when comparing alcoholics to cocaine addicts, with the profile generally worse in alcoholics except for a few variables directly related to cocaine consumption. Specifically, debts due to consumption and the presence of hallucinations were variables more frequently observed in cocaine addicts.

On the other hand, results of the multivariate analysis carried out showed that variables related to severity of the addiction were the main predictors of belonging to alcoholics group or cocaine addicts group. Similar results were found when men and women were analysed separately. According to these results, the specific dependence of a substance seems to be the most relevant variable to predict the belonging group, in both men and women. Anyway, gender differences in addiction have recently shown to be an important variable to take into account when studying and treating substance dependent patients (Fernández-Montalvo, López-Goñi, Azanza, \& Cacho, 2014).

Therefore, according to these results, treatment programs for alcoholism should consider, beyond the drinking itself, the problems observed in other areas of daily life for these patients. Inattention to these aspects of life (family, social, occupational, medical, etc.) could decisively influence the recovery of these patients and increase their relapse rates (Bodin \& Romelsjo, 2007; Echeburúa, de Medina, \& Aizpiri, 2008; ). In addition to immediate alcohol consumption, factors that maintain long-term consumption must be addressed. Appropriate social, familiar, labour and medical support during the treatment process may help the recovery of these patients. In contrast, patients addicted to cocaine show better adjustment to everyday life (McKay et al., 2013), and their problems seem to be more focused on the immediate impact directly related to consumption. Consequently, intervention should focus on the factors that encourage short-term consumption, mainly 
during the leisure period on the weekend. In both cases, situational elements appear more important than personality dimensions or psychopathological characteristics in establishing the type of treatment that could be more adequate for drug-addicted patients. This generates a therapeutic optimism and encouragement to carefully design individually-tailored strategies to improve treatment results. For example, as it has been highlighted by Tryon and Winograd (2011), better outcomes can be expected when patients and therapist agree on therapeutic goals and the processes to achieve these goals, according to real needs of patients.

Several limitations of the present study must be taken into consideration. The first is related to the sample that was evaluated. Although our study included a relatively large sample of patients who were being treated for drug abuse, only $19.2 \%$ of the sample were women. There are reasons to believe that women who suffer from drug addictions have different problems from those of addicted men. Moreover, the present study only included patients who completed the assessment; patients who did not complete the three assessment sessions were not considered. We assume that patients who withdraw from a treatment programme at an early stage have different profiles from those of the patients who were analysed in this study. For all of these reasons, we must be cautious when attempting to generalise our results. Moreover, in this study psychopathological symptoms have been evaluated with a self-report (the SCL-90-R). Due to the importance of these types of symptoms, it would be interesting to assess them with a structured interview in future studies.

In conclusion, the results of this study show that patients with alcohol dependence and cocaine dependence have different profiles, with different repercussions for important areas of life. Consequently, these differences should be taken into account 
when standard treatments for addiction are implemented. Addressing these factors is likely to be the best way to improve the effectiveness of the interventions and to decrease the rate of dropouts and relapses.

\section{Acknowledgments}

This study was supported by a grant (Res. 359/2012) from the Health Department of Navarre Government (Spain). The authors thank the "Proyecto Hombre de Navarra" programme staff for their help in assessing the clinical sample.

\section{Declaration of Interest}

The authors report no conflicts of interest. The authors alone are responsible for the content and writing of this paper.

López-Goñi, J., Fernández-Montalvo, J., \& Arteaga, A. (2015). Differences between Alcoholics and Cocaine Addicts Seeking Treatment. The Spanish Journal of Psychology, 18, E2. doi:10.1017/sjp.2015.3 


\section{References}

American Psychiatric Association. (2000). Diagnostic and Statitical Manual: Mental Disorders (4th Ed. Rev.). Washington D.C.: APA.

Araque, F., De los Riscos, M., De la Casa, L., \& López-Torrecillas, F. (2004).

Trastornos de personalidad: una comparación entre consumidores de heroína, cocaína y alcohol [Personality disorders: a comparison between patients addicted to heroin, cocaine and alcohol]. Revista Española de Drogodependencias(29), 224-237.

Arias, F., Szerman, N., Vega, P., Mesías, B., Basurte, I., Morant, C., . . . Babín, F. (2013). Estudio Madrid sobre prevalencia y características de los pacientes con patología dual en tratamiento en las redes de salud mental y de atención al drogodependiente [Madrid study on the prevalence and characteristics of outpatients with dual pathology in community mental health and substance misuse services]. Adicciones, 25(2), 118-127.

Arteaga, A., Fernández-Montalvo, J., \& López-Goñi, J. J. (2012). Diferencias en variables de personalidad en sujetos adictos a drogas con y sin conductas violentas contra la pareja [Differences in personality variables in drug-addicted patients with and without intimate partner violence]. Acción Psicológica, 9(1), 19-32.

Asociación Proyecto Hombre. (2013). Informe 2012. Observatorio Proyecto Hombre sobre el perfil del drogodependiente [Report 2012. Observatory Proyecto Hombre on the profile of drug addicts]. In A. P. Hombre (Ed.). Madrid.

Bobes, J., Bascarán, M. T., Bobes-Bascarán, M. T., Carballo, J. L., Díaz, E. M., Flórez, G., . . . Sáiz, P. A. (2008). Valoración de la gravedad de la adicción: aplicación a la gestión clínica y monitorización de los tratamientos [Assessment of the severity of addition: application to clinical management and treatment monitoring]. Barcelona: Socidrogalcohol.

Bobes, J., González, M. P., Saiz, P. A., \& Bousoño, M. (1996). Índice Europeo de Severidad de la Adicción: EuropASI. Versión española [European Index of Severity of Addiction: EuropASI. Spanish Version]. Paper presented at the Actas de la IV Reunión Interregional de Psiquiatría.

López-Goñi, J., Fernández-Montalvo, J., \& Arteaga, A. (2015). Differences between Alcoholics and Cocaine Addicts Seeking Treatment. The Spanish Journal of Psychology, 18, E2. 
Bodin, M. C., \& Romelsjo, A. (2007). Secondary outcomes: Group and individual change and relationships to drinking outcomes. Addiction Research \& Theory, 15, 587-599.

Bravo de Medina, R., Echeburúa, E., \& Aizpiri, J. (2007). Características psicopatológicas y dimensiones de personalidad en los pacientes dependientes del alcohol: un estudio comparativo [Psychopathological symptoms and personality traits in alcohol-dependent patients: A comparative study]. Adicciones(19), 373-381.

Derogatis, L. R. (1992). The SCL-90-R. Baltimore: Clinical Psychometric Research. Echeburúa, E., de Medina, R. B., \& Aizpiri, J. (2008). Variables de personalidad, alteraciones psicopatológicas y trastornos de personalidad en pacientes con dependencia de alcohol en función de la tipología de Cloninger [Personality variables, psychopathological alterations and personality disorders in alcoholdependent patients according to Cloninger's typology of alcohol abuse]. Psicothema, 20(4), 525-530.

Fernández-Montalvo, J., \& López-Goñi, J. J. (2010). Comparison of completers and dropouts in psychological treatment for cocaine addiction. Addiction Research \& Theory, 18(4), 433-441. http://dx.doi.org/10.3109/16066350903324826 Fernández-Montalvo, J., López-Goñi, J. J., \& Arteaga, A. (2012a). Prevalence of pathological gambling in treatment-seeking addicted patients: An exploratory study with the South Oaks Gambling Screen. Anales de Psicología, 28(2), 344349. http://dx.doi.org/10.6018/analesps.28.2.147611

Fernández-Montalvo, J., López-Goñi, J. J., \& Arteaga, A. (2012b). Violent behaviours in drug addiction: Differential profiles of drug-addicted patients with and without violence problems. Journal of Interpersonal Violence, 27, 142-157.

Fernández-Montalvo, J., López-Goñi, J. J., Arteaga, A., \& Cacho, R. (2013).

Criminological profile of patients in addiction treatment. Adicciones, 25(2), 146155. http://dx.doi.org/10.1177/0886260511416475

Fernández-Montalvo, J., López-Goñi, J.J., Azanza, P. \& Cacho, R. (2014). Gender differences in drug-addicted patients in clinical treatment center of Spain. American Journal on Addictions, 23, 399-406. http://dx.doi.org/10.1111/j.1521$\underline{0391.2013 .12117 . \mathrm{x}}$

López-Goñi, J., Fernández-Montalvo, J., \& Arteaga, A. (2015). Differences between Alcoholics and Cocaine Addicts Seeking Treatment. The Spanish Journal of Psychology, 18, E2. doi:10.1017/sjp.2015.3 
Fernández-Montalvo, J., López-Goñi, J. J., Illescas, C., Landa, N., \& Lorea, I. (2008).

Evaluation of a therapeutic community treatment program: A long-term followup study in Spain. Substance Use \& Misuse, 43(10), 1362-1377.

http://dx.doi.org/10.1080/10826080801922231

González de Rivera, J. L. (2002). Versión española del SCL-90-R [Spanish version of the SCL-90-R]. Madrid: TEA.

Hatton, J., Burton, A., Nash, H., Munn, E., Burgoyne, L., \& Sheron, N. (2009).

Drinking patterns, dependency and life-time drinking history in alcohol-related liver disease. Addiction, 104(4), 587-592. http://dx.doi.org/10.1111/j.1360$\underline{0443.2008 .02493 . x}$

Koeter, M. W. J., \& Hartgers, C. (1997). European addiction severity index europasi. Cost a6. Preliminary procedure for the computation of the europasi composite scores. The Amsterdam Institute for Addiction Research. Amsterdam.

Kokkevi, A., \& Hartgers, C. (1995). European adaptation of a multidimensional assessment instrument for drug and alcohol dependence. European Addiction Research, 1, 208-210. http://dx.doi.org/10.1159/000259089

Landa, N., Fernández-Montalvo, J., López-Goñi, J. J., \& Lorea, I. (2006). Comorbilidad psicopatológica en el alcoholismo: un estudio descriptivo [Psychopathological comorbidity in alcoholism: a descriptive study]. International Journal of Clinical and Health Psychology, 6(2), 253-269.

Lorea, I., Fernández-Montalvo, J., López-Goñi, J., \& Landa, N. (2009). Adicción a la cocaína y trastornos de personalidad: un estudio con el MCMI-II [Cocaine addiction and personality disorders: a study with the MCMI-II]. Adicciones, 21(1), 57-63.

López-Goñi, J. J., Fernández-Montalvo, J., \& Arteaga, A. (2012a). Addiction treatment dropout: Exploring patients' characteristics. American Journal on Addictions, 21(1), 78-85. http://dx.doi.org/10.1111/j.1521-0391.2011.00188.x

López-Goñi, J. J., Fernández-Montalvo, J., \& Arteaga, A. (2012b). Predictive validity of the EuropASI: Clinical diagnosis or composite scoring? Journal of Substance Abuse Treatment, 42, 392-399. http://dx.doi.org/10.1016/j.jsat.2011.09.011

López-Goñi, J. J., Fernández-Montalvo, J., Menéndez, J. C., Yudego, F., García, A. R., \& Esarte, S. (2010). Group and individual change in the treatment of drug

López-Goñi, J., Fernández-Montalvo, J., \& Arteaga, A. (2015). Differences between Alcoholics and Cocaine Addicts Seeking Treatment. The Spanish Journal of Psychology, 18, E2. doi:10.1017/sjp.2015.3 
addictions: A follow-up study in Therapeutic Communities. Spanish Journal of Psychology, 13(2), 906-913.

McKay, J. R., Van Horn, D., Rennert, L., Drapkin, M., Ivey, M., \& Koppenhaver, J. (2013). Factors in sustained recovery from cocaine dependence. Journal of Substance Abuse Treatment, 45(2), 163-172. http://dx.doi.org/10.1016/j.jsat.2013.02.007

McLellan, A. T., Luborsky, L., Woody, G. E., \& O’Brien, C. P. (1980). An improved diagnostic evaluation instrument for substance abuse patients: The Addiction Severity Index. The Journal of Nervous and Mental Disease, 168(1), 26-33. Millon, T. (1997). Millon Clinical Multiaxial Inventory- II (MCMI II). Minneapolis: National Computer Systems.

Millon, T., \& Ávila, A. (1998). Inventario Clínico Multiaxial de Millon (MCMI-II). Madrid: TEA Ediciones.

National Institute on Drug Abuse. (2003). Preventing drug use among children and adolescents: a research-based guide for parents, educators, and community leaders. Maryland: U.S. Department of Health and Human Services.

Observatorio Español de la Droga y las Toxicomanías. (2011). Informe 2011. Situación y tendencias de los problemas de drogas en España [Report 2011. Status and trends of drug problems in Spain]. In P. S. e. I. Ministerio de Sanidad (Ed.). Madrid.

Secades, R., \& Fernández-Hermida, J. R. (2003). Guía de tratamientos psicológicos eficaces para la drogadicción: alcohol, cocaína y heroína [Guide effective psychological treatments for drug addiction: alcohol, cocaine and heroin]. In M. Pérez, J. R. Fernández-Hermida, C. Fernández \& I. Amigo (Eds.), Guía de tratamientos psicológicos eficaces I [Guide effective psychological treatments I] (pp. 107-139). Madrid: Pirámide.

Sánchez-Hervás, E., Tomás Gradolí, V., \& Morales Gallús, E. (2001). Evaluación psicopatológica en dependientes al alcohol, heroína y cocaína mediante el Brief Symptom Inventory [Psychophatological evaluation in alcohol, heroin and cocaine dependents through brief symton inventory]. Adicciones, 13, 61-66.

Tryon, G. S. \& Winograd, G. (2011). Goal consensus and collaboration. Psychotherapy, 48, 50-57. http://dx.doi.org/10.1037/a0022061

López-Goñi, J., Fernández-Montalvo, J., \& Arteaga, A. (2015). Differences between Alcoholics and Cocaine Addicts Seeking Treatment. The Spanish Journal of Psychology, 18, E2. doi:10.1017/sjp.2015.3 
Table 1

Comparisons of socio-demographic and drug abuse characteristics

\begin{tabular}{|c|c|c|c|c|c|c|c|}
\hline & \multicolumn{2}{|c|}{$\begin{array}{c}\text { All } \\
(N=234)\end{array}$} & \multicolumn{2}{|c|}{$\begin{array}{l}\text { Alcohol } \\
(n=109)\end{array}$} & \multicolumn{2}{|c|}{$\begin{array}{l}\text { Cocaine } \\
(n=125)\end{array}$} & \multirow[b]{2}{*}{$t(d f)$} \\
\hline & Mean & (SD) & Mean & (SD) & Mean & (SD) & \\
\hline \multirow[t]{3}{*}{ Mean age } & 37.8 & (9.4) & 44.1 & (8.3) & 32.2 & (6.3) & $12.2 * * *(198.8)$ \\
\hline & \multicolumn{2}{|c|}{$\begin{array}{c}\text { All } \\
(N=234)\end{array}$} & \multicolumn{2}{|c|}{$\begin{array}{l}\text { Alcohol } \\
(n=109)\end{array}$} & \multicolumn{2}{|c|}{$\begin{array}{c}\text { Cocaine } \\
(n=125)\end{array}$} & \\
\hline & $N$ & (\%) & $n$ & $(\%)$ & $n$ & $(\%)$ & $X^{2}(d f)$ \\
\hline \multicolumn{8}{|l|}{ Sex } \\
\hline Men & 189 & $(80.8 \%)$ & 82 & (75.2\%) & 107 & $(85.6 \%)$ & \multirow{2}{*}{$4.0 *(1)$} \\
\hline Women & 45 & $(19.2 \%)$ & 27 & $(24.8 \%)$ & 18 & $(14.4 \%)$ & \\
\hline
\end{tabular}

Marital Status

\begin{tabular}{|c|c|c|c|c|c|c|c|}
\hline Single & 116 & (49.6\%) & 35 & (32.1\%) & 81 & (64.8\%) & \multirow{3}{*}{$25.1^{* * *}(2)$} \\
\hline Married & 67 & $(28.6 \%)$ & 41 & $(37.6 \%)$ & 26 & $(20.8 \%)$ & \\
\hline Divorced & 51 & $(21.8 \%)$ & 33 & (30.3\%) & 18 & (14.4\%) & \\
\hline
\end{tabular}

\section{Education}

\begin{tabular}{lccccccc}
\hline None & 27 & $(11.6 \%)$ & 17 & $(15.7 \%)$ & 10 & $(8.0 \%)$ \\
\hline Primary school & 126 & $(54.1 \%)$ & 55 & $(50.9 \%)$ & 71 & $(56.8 \%)$ & $11.3 *(3)$ \\
\hline Secondary school & 57 & $(24.5 \%)$ & 20 & $(18.5 \%)$ & 37 & $(29.6 \%)$ & \\
\hline University & 23 & $(9.9 \%)$ & 16 & $(14.8 \%)$ & 7 & $(5.6 \%)$ \\
\hline
\end{tabular}

\section{Employment situation}

\begin{tabular}{|c|c|c|c|c|c|c|c|}
\hline Employed & 156 & $(66.7 \%)$ & 66 & $(60.6 \%)$ & 90 & $(72.0 \%)$ & \multirow{3}{*}{$6.2 *(2)$} \\
\hline Unemployed & 60 & $(25.6 \%)$ & 30 & $(27.5 \%)$ & 30 & $(24.0 \%)$ & \\
\hline Other (student, retired, etc.) & 18 & $(7.7 \%)$ & 13 & $(11.9 \%)$ & 5 & $(4.0 \%)$ & \\
\hline Poly-dependence & 55 & $(23.5 \%)$ & 16 & $(14.7 \%)$ & 39 & $(31.2 \%)$ & $8.8 * *(1)$ \\
\hline \multicolumn{8}{|l|}{ Frequency of consumption } \\
\hline Every_day & 128 & $(54.7 \%)$ & 69 & $(63.3 \%)$ & 59 & $(47.2 \%)$ & \multirow{3}{*}{$7.0 *(2)$} \\
\hline 4-6 days /week & 21 & $(9.0 \%)$ & 6 & $(5.5 \%)$ & 15 & $(12.0 \%)$ & \\
\hline$<4$ days /week & 85 & (36.3) & 34 & $(31.2 \%)$ & 51 & $(40.8 \%)$ & \\
\hline
\end{tabular}

${ }^{*} p<.01 ; \quad \quad{ }^{* *} p<.01 ; \quad \quad{ }^{* * *} p<.001$

López-Goñi, J., Fernández-Montalvo, J., \& Arteaga, A. (2015). Differences between Alcoholics and Cocaine Addicts Seeking Treatment. The Spanish Journal of Psychology, 18, E2. 
Table 2

Comparisons of drug addiction severity variables

\begin{tabular}{lcccc}
\hline & $\begin{array}{c}\text { All } \\
(\boldsymbol{N}=\mathbf{2 3 4})\end{array}$ & $\begin{array}{c}\text { Alcohol } \\
(\boldsymbol{n}=\mathbf{1 0 9})\end{array}$ & $\begin{array}{c}\text { Cocaine } \\
(\boldsymbol{n}=\mathbf{1 2 5})\end{array}$ & \\
\hline EuropASI CS & $\boldsymbol{M}(\boldsymbol{S D})$ & $\boldsymbol{M}(\boldsymbol{S D})$ & $\boldsymbol{M}(\boldsymbol{S D})$ & $\boldsymbol{t}(\boldsymbol{d} \boldsymbol{f})$ \\
\hline Medical & $0.22(0.25)$ & $0.25(0.28)$ & $0.19(0.23)$ & $1.9(208.0)$ \\
\hline Economic situation & $0.38(0.45)$ & $0.48(0.47)$ & $0.29(0.41)$ & $3.3^{* *}(216.8)$ \\
\hline Labour satisfaction & $0.27(0.32)$ & $0.28(0.33)$ & $0.26(0.32)$ & $0.5(232.0)$ \\
\hline Alcohol & $0.32(0.24)$ & $0.41(0.23)$ & $0.24(0.22)$ & $5.8^{* * *}(232.0)$ \\
\hline Drug use & $0.09(0.08)$ & $0.03(0.07)$ & $0.19(0.09)$ & $14.4^{* * *}(227.4)$ \\
\hline Legal & $0.13(0.21)$ & $0.13(0.22)$ & $0.13(0.20)$ & $0.1(231.0)$ \\
\hline Family & $0.27(0.23)$ & $0.29(0.23)$ & $0.26(0.24)$ & $1.0(232.0)$ \\
\hline Others & $0.15(0.18)$ & $0.14(0.18)$ & $0.16(0.19)$ & $1.1(230.0)$ \\
\hline Psychiatric & $0.21(0.19)$ & $0.24(0.21)$ & $0.19(0.18)$ & $1.7(225.0)$
\end{tabular}

\section{EuropASI ISR}

\begin{tabular}{llllc}
\hline Medical & $2.0(1.4)$ & $2.2(1.6)$ & $1.8(1.1)$ & $2.3^{*}(188.9)$ \\
\hline Employment/Support & $2.4(1.7)$ & $2.6(2.0)$ & $2.1(1.3)$ & $2.2^{*}(180.1)$ \\
\hline Alcohol use & $4.0(2.0)$ & $5.3(1.5)$ & $2.9(1.7)$ & $11.5^{* * *}(232.0)$ \\
\hline Drugs use & $3.2(2.1)$ & $1.8(1.9)$ & $4.5(1.2)$ & $13.3^{* * *}(173.9)$ \\
\hline Legal & $1.7(1.5)$ & $1.4(1.3)$ & $2.0(1.5)$ & $3.6^{* * *(232.0)}$ \\
\hline Family/Social & $3.6(1.7)$ & $3.9(1.8)$ & $3.4(1.6)$ & $2.3^{*}(231.0)$ \\
\hline Psychiatric & $3.2(1.8)$ & $3.5(1.9)$ & $3.0(1.6)$ & $2.2^{*}(214.3)$ \\
\hline
\end{tabular}

$\mathrm{CS}=$ Composite Scores

ISR = Interviewer Severity Ratings

$$
{ }^{*} p<.05 ; * * p<.01 ; * * * p<.001
$$

López-Goñi, J., Fernández-Montalvo, J., \& Arteaga, A. (2015). Differences between Alcoholics and Cocaine Addicts Seeking Treatment. The Spanish Journal of Psychology, 18, E2. 
Table 3

Comparisons of clinical variables

\begin{tabular}{|c|c|c|c|c|}
\hline & $\begin{array}{c}\text { All } \\
(N=234)\end{array}$ & $\begin{array}{l}\text { Alcohol } \\
(n=109)\end{array}$ & $\begin{array}{l}\text { Cocaine } \\
(n=125)\end{array}$ & \\
\hline & $n(\%)$ & $n(\%)$ & $n(\%)$ & $X^{2}(d f)$ \\
\hline Dropouts & $95(40.6 \%)$ & $50(45.9 \%)$ & $45(36.0 \%)$ & $2.3(1)$ \\
\hline SCL-90-R (percentiles) & $M(S D)$ & $M(S D)$ & $M(S D)$ & $t(d f)$ \\
\hline GSI & $64.4(33.0)$ & $69.1(32.5)$ & 60.2 (33.3) & $2.1 *(232)$ \\
\hline PSDI & $47.4(31.9)$ & $54.6(31.7)$ & $41.1(30.8)$ & $3.3^{* *}(232)$ \\
\hline PST & $68.5(31.9)$ & $69.4(32.3)$ & $67.6(31.6)$ & $0.4(232)$ \\
\hline Somatisation & $57.9(32.3)$ & $60.7(33.1)$ & $55.4(31.5)$ & $1.3(232)$ \\
\hline Obsessive-compulsive & $60.9(33.2)$ & $61.4(34.0)$ & $60.5(32.6)$ & $0.2(232)$ \\
\hline Interpersonal sensitivity & $62.8(33.6)$ & $65.6(33.9)$ & $60.3(33.3)$ & $1.2(232)$ \\
\hline Depression & $60.8(33.0)$ & $66.1(32.9)$ & $56.2(32.6)$ & $2.3 *(232)$ \\
\hline Anxiety & 56.7 (33.9) & $60.6(34.8)$ & $53.4(32.9)$ & $1.6(232)$ \\
\hline Hostility & $51.7(33.1)$ & $53.8(34.2)$ & $50.0(32.1)$ & $0.9(232)$ \\
\hline Phobic anxiety & $53.1(36.8)$ & $55.1(36.2)$ & $51.4(37.4)$ & $0.8(232)$ \\
\hline Paranoid ideation & $61.0(33.2)$ & $62.9(33.8)$ & $59.4(32.9)$ & $0.8(232)$ \\
\hline Psychoticism & $67.8(33.0)$ & $73.4(30.5)$ & $62.8(34.4)$ & $2.5 *(231.9)$ \\
\hline \multicolumn{5}{|l|}{ MCMI-II } \\
\hline Schizoid & $59.2(27.8)$ & $65.0(31.8)$ & $54.1(22.7)$ & $3.1^{* *}(232)$ \\
\hline Phobic & $49.7(28.0)$ & 54.7 (28.3) & $45.4(27.0)$ & $2.6^{*}(232)$ \\
\hline Dependence & $60.1(24.1)$ & $62.5(24.3)$ & $58.1(23.9)$ & $1.4(232)$ \\
\hline Histrionic & $53.5(20.0)$ & $51.8(20.8)$ & $54.9(19.2)$ & $1.2(232)$ \\
\hline Narcissistic & $50.3(23.8)$ & $51.6(23.2)$ & $49.1(24.4)$ & $0.8(232)$ \\
\hline Antisocial & $52.3(23.7)$ & $53.8(23.7)$ & $51.0(23.7)$ & $0.9(232)$ \\
\hline Aggressive-sadistic & $52.2(23.3)$ & $54.7(23.8)$ & $50.0(22.8)$ & $1.5(232)$ \\
\hline Compulsive & $55.0(20.7)$ & $58.7(19.6)$ & $51.7(21.1)$ & $2.6^{* *}(232)$ \\
\hline Passive-aggressive & $45.1(30.3)$ & $48.1(30.0)$ & $42.4(30.4)$ & $1.5(232)$ \\
\hline Self-destructive & 48.3 (23.9) & $51.9(25.3)$ & $45.3(22.3)$ & $2.1 *(232)$ \\
\hline Schizotypal & $42.0(23.5)$ & $47.1(22.3)$ & $37.5(23.7)$ & $3.2 * *(230.6)$ \\
\hline Borderline & $39.6(26.0)$ & 40.9 (26.3) & 38.5 (25.8) & $0.7(232)$ \\
\hline Paranoid & $56.0(17.0)$ & $58.3(16.7)$ & $54.0(17.0)$ & $2.0 *(232)$ \\
\hline
\end{tabular}

López-Goñi, J., Fernández-Montalvo, J., \& Arteaga, A. (2015). Differences between Alcoholics and Cocaine Addicts Seeking Treatment. The Spanish Journal of Psychology, 18, E2.

doi:10.1017/sjp.2015.3 
Table 4

Comparisons of maladjustment variables

\begin{tabular}{|c|c|c|c|c|c|c|}
\hline & & \multicolumn{2}{|r|}{ All } & \multirow{2}{*}{$\begin{array}{c}\text { Alcohol } \\
(\mathrm{n}=109) \\
n \quad(\%)\end{array}$} & \multirow[t]{2}{*}{$\begin{array}{c}\text { Cocaine } \\
(\mathrm{n}=125) \\
n \quad(\%)\end{array}$} & \multirow[t]{2}{*}{$\begin{array}{c}X^{2} \\
(d f=1)\end{array}$} \\
\hline & & $N$ & $n(\%)$ & & & \\
\hline \multicolumn{7}{|c|}{ Family maladjustment } \\
\hline \multirow{5}{*}{ Problems with } & Mother & 231 & 65 (28.1\%) & $30(27.8 \%)$ & $35(28.5 \%)$ & 0 \\
\hline & Father & 223 & 76 (34.1\%) & $33(32.0 \%)$ & $43(35.8 \%)$ & 0.4 \\
\hline & Brothers/Sisters & 224 & 72 (32.1\%) & $42(39.3 \%)$ & $30(25.6 \%)$ & $4.8^{*}$ \\
\hline & Sexual partner & 222 & $133(59.9 \%)$ & $64(62.1 \%)$ & $69(58.0 \%)$ & 0.4 \\
\hline & Sons/Daughters & 109 & $15(13.8 \%)$ & $12(16.9 \%)$ & $3(7.9 \%)$ & 1.7 \\
\hline \multicolumn{7}{|c|}{ Social maladjustment } \\
\hline \multirow{3}{*}{ Problems with } & Intimate friends & 225 & 57 (25.3\%) & $19(18.6 \%)$ & $38(30.9 \%)$ & $4.4^{*}$ \\
\hline & Neighbours & 230 & $28(12.2 \%)$ & $15(14.3 \%)$ & $13(10.4 \%)$ & 0.8 \\
\hline & Work colleagues & 230 & 65 (28.3\%) & $35(33.3 \%)$ & $30(24.0 \%)$ & 2.4 \\
\hline \multicolumn{7}{|c|}{ Labour maladjustment } \\
\hline \multicolumn{2}{|c|}{$\begin{array}{l}\text { Without permanent job during the } \\
\text { last } 3 \text { years }\end{array}$} & 234 & 36 (15.4\%) & $24(22.0 \%)$ & $12(9.6 \%)$ & $6.9 * *$ \\
\hline \multicolumn{7}{|c|}{ Economic maladjustment } \\
\hline \multicolumn{2}{|c|}{ Debts due to consumption } & 234 & $100(42.7 \%)$ & $36(33.0 \%)$ & $64(51.2 \%)$ & $7.9^{* *}$ \\
\hline \multicolumn{7}{|c|}{ Victim of abuse } \\
\hline \multirow{3}{*}{ Type of abuse } & Psychological & 233 & $97(41.6 \%)$ & $46(42.6 \%)$ & $51(40.8 \%)$ & 0.1 \\
\hline & Physical & 232 & $42(18.1 \%)$ & $24(22.4 \%)$ & $18(14.4 \%)$ & 2.5 \\
\hline & Sexual & 233 & $20(8.6 \%)$ & $13(12.0 \%)$ & $7(5.6 \%)$ & 3.1 \\
\hline \multicolumn{7}{|c|}{ Psychological maladjustment } \\
\hline \multicolumn{2}{|c|}{ Depressive problems } & 234 & $121(51.7 \%)$ & $67(61.5 \%)$ & $54(43.2 \%)$ & $7.8^{* *}$ \\
\hline \multicolumn{2}{|c|}{ Anxiety problems } & 234 & 139 (59.4\%) & $74(67.9 \%)$ & $65(52.0 \%)$ & $6.1^{*}$ \\
\hline \multicolumn{2}{|l|}{ Hallucinations } & 234 & $34(14.5 \%)$ & $10(9.2 \%)$ & $24(19.2 \%)$ & $4.7^{*}$ \\
\hline \multicolumn{2}{|c|}{ Violence problems } & 234 & $90(38.5 \%)$ & $43(39.4 \%)$ & $47(37.6 \%)$ & 0.1 \\
\hline \multicolumn{2}{|l|}{ Suicide ideation } & 234 & $93(39.7 \%)$ & $47(43.1 \%)$ & $46(36.8 \%)$ & 0.1 \\
\hline \multicolumn{2}{|l|}{ Suicide attempt } & 232 & 38 (16.4\%) & $20(18.7 \%)$ & $18(14.4 \%)$ & 0.8 \\
\hline
\end{tabular}

${ }^{*} p<.05 ;{ }^{* *} p<.01 ;{ }^{* * *} p<.001$

López-Goñi, J., Fernández-Montalvo, J., \& Arteaga, A. (2015). Differences between Alcoholics and Cocaine Addicts Seeking Treatment. The Spanish Journal of Psychology, 18, E2.

doi:10.1017/sjp.2015.3 
Table 5

Multivariate analysis (final models)

Logistic Regression (Dependent variable = Substance; 0 = Alcohol; 1 = Cocaine)

\begin{tabular}{|c|c|c|c|c|c|c|c|c|c|}
\hline & \multicolumn{3}{|c|}{ Model 1: Sociodemographic } & \multicolumn{3}{|c|}{ Model 2: Severity of addiction } & \multicolumn{3}{|c|}{ Model 3: Clinical variables } \\
\hline & Var. & OR & $95 \% \mathrm{CI}$ & Var. & OR & $95 \% \mathrm{CI}$ & Var. & OR & $95 \%$ CI \\
\hline All & Age & $0.8^{* * *}$ & $(0.72,0.83)$ & ISR alcohol & $0.2^{* * *}$ & $(0.10,0.40)$ & Obsessive-compulsive & $1.02 * *$ & $(1.01,1.03)$ \\
\hline & Sex (Men) & $5.9 * *$ & $(2.20,15.90)$ & ISR drugs & $5.5 * * *$ & $(3.10,9.50)$ & Psychoticism & $0.99 *$ & $(0.97,0.99)$ \\
\hline & Ed (Secondary) & $4.0^{*}$ & $(1.00,16.10)$ & CS economic & $0.2^{*}$ & $(0.50,0,80)$ & PSDI & $0.98 * *$ & $(0.97,0.99)$ \\
\hline Adj. $R^{2}$ & $\begin{array}{l}\text { Constant } \\
.595\end{array}$ & $2857 * * *$ & & $\begin{array}{l}\text { Constant } \\
.837\end{array}$ & 1.8 & & $\begin{array}{l}\text { Constant } \\
.173\end{array}$ & $2.3^{*}$ & \\
\hline C. classified & $84.1 \%$ (Total) & 82.4 (Alcohol) & $85.6 \%$ (Cocaine) & $90.1 \%$ (Total) & 86.9\% (Alcohol) & 90.5\% (Cocaine) & $61.1 \%$ (Total) & $55.0 \%$ (Alcohol) & $66.4 \%$ (Cocaine) \\
\hline Male & Age & $0.7 * * *$ & $(0.69,0.82)$ & ISR alcohol & $0.2 * * *$ & $(0.10,0.40)$ & PSDI & $0.98 * *$ & $(0.98,0.99)$ \\
\hline Adj. $\mathrm{R}^{2}$ & $\begin{array}{l}\text { Constant } \\
.622\end{array}$ & $146611.3^{* * *}$ & & $\begin{array}{l}\text { ISR drugs } \\
\text { Constant } \\
.798\end{array}$ & $\begin{array}{c}4.2 * * * \\
3.0\end{array}$ & $(2.60,6.70)$ & $\begin{array}{l}\text { Constant } \\
.053\end{array}$ & $2.51^{* *}$ & \\
\hline C. classified & 83.5\% (Total) & 79.0\% (Alcohol) & 86.9\% (Cocaine) & $88,8 \%$ (Total) & 86.5\% (Alcohol) & 90.5\% (Cocaine) & $59.8 \%$ (Total) & 35.4\% (Alcohol) & 78.5\% (Cocaine) \\
\hline Adj. $\mathrm{R}^{2}$ & $\begin{array}{l}\begin{array}{l}\text { Age } \\
\text { Constant }\end{array} \\
0.435\end{array}$ & $\begin{array}{c}0.82^{* *} \\
727.30^{* *}\end{array}$ & $(0.72,0.93)$ & $\begin{array}{l}\text { ISR alcohol } \\
\text { CS drugs } \\
\text { Constant } \\
1.0\end{array}$ & $\begin{array}{c}0 \\
1.3 \mathrm{E}+261 \\
4.1 \mathrm{E}+043\end{array}$ & $\begin{array}{l}(0, .) \\
(0, .) \\
(0, .)\end{array}$ & Constant & 0.67 & \\
\hline C. classified & 73.3\% (Total) & 85.2\% (Alcohol) & $55.6 \%$ (Cocaine) & $100 \%$ (Total) & 100\% (Alcohol) & 100\% (Cocaine) & $60.0 \%$ (Total) & $100 \%$ (Alcohol) & $0 \%$ (Cocaine) \\
\hline
\end{tabular}

Adj. = Adjusted; Ed. = Education; C. classified = Correctly classified; PSDI = Positive Symptom Distress Index

$* p<.05 ; * * p<.01 ; * * * p<.001$

López-Goñi, J., Fernández-Montalvo, J., \& Arteaga, A. (2015). Differences between Alcoholics and Cocaine Addicts Seeking Treatment. The Spanish Journal of Psychology, 18, E2. doi:10.1017/sjp.2015.3 